\title{
Urological Diseases: Ruqya and Negative Ions Treatment
}

\author{
Mira Bajirova* \\ Department of Gynecology \& Obstetrics, Health care, UAE
}

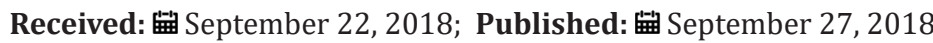

*Corresponding author: Mira Bajirova, Associate Professor, Consultant Ob-Gyn, IVF (Paris), Health Care, Dubai, UAE

\begin{abstract}
Urological diseases have two groups of causes: Decreased Oxygen Utilization and Jinn. Decreased Oxygen Utilization is caused by Positive Ions from man-made activities. Positive ions induce acidity and inflammation in our body, which are at the base of almost all diseases; the best treatment against Positive Ions is the use of Negative Ions, while Medicine is powerless in many cases. What is amazing, that the Negative Ions help also to diagnose the presence of the Jinn as a cause of the disease and remove the Evil of Satan as Allah "sent down upon you from the sky, rain by which to purify you and remove from you the evil (suggestions) of Satan and to make steadfast your hearts and plant firmly thereby your feet." (Quran, Al Anfal 8:11). During the rain and thunderstorm there is a massive discharge of Negative Ions. Jinn contain more Positive Ions. The cure is only by Allah and when Ruqya is associated with Negative Ions the cure is quicker.
\end{abstract}

Keywords: Decreased Oxygen Utilization; Positive Ions; Negative Ions; Jinn; Ruqya

\section{INTRODUCTION}

The causes of the Urological Diseases can be divided in two groups:

I. Diseases created by Decreased Oxygen Utilization (Positive Ions)

II. Diseases created by Jinn (Black Magic, Jinn (Demonic) Possession, and Evil Eye)

\section{DISEASES CAUSED BY DECREASED OXYGEN UTILIZATION}

Oxygen is the most important nutrient that we take in. Inspired oxygen from the environment moves across the alveolocapillary membrane into the blood. Most of the oxygen binds to hemoglobin in red blood cells, although a small amount dissolves into the plasma. The oxygen is then transported from the lungs to the peripheral tissues, where it is removed from the blood and used to fuel aerobic cellular metabolism. This process can be conceptualized as three steps: oxygenation, oxygen delivery, and oxygen consumption. Decreased Oxygen Utilization exerts its negative effects by decreasing the NAD/NADH ratio. Mitochondrial dysfunction is a principal cause of the degenerative diseases, aging and infertility. Mitochondria provide energy for basic metabolic processes, and their decay impairs cellular metabolism and leads to cellular decline, damage (Figure 1).

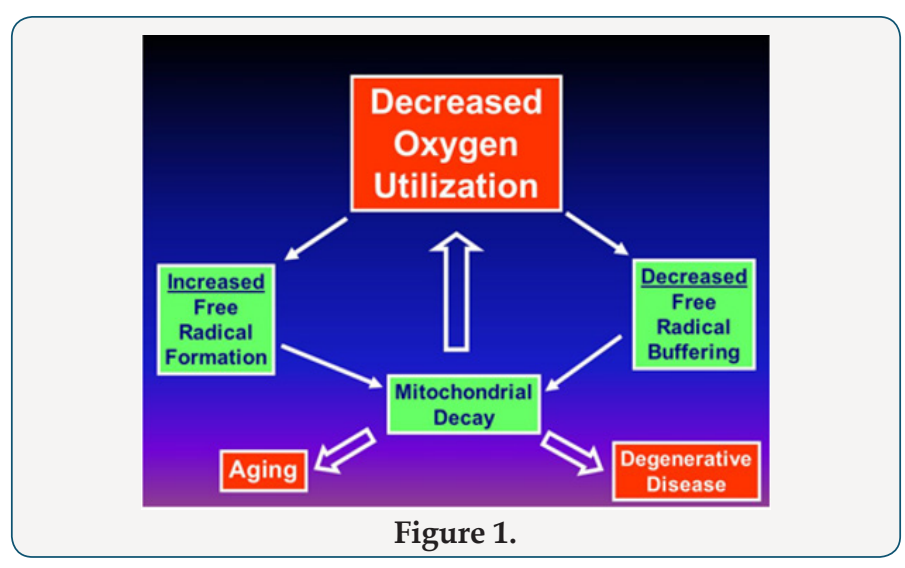

Decreased Oxygen Utilization is caused by Positive Ions, which increase Acidity and Inflammation, the main cause of almost all diseases. Positive Ions are the atoms or molecules which are created by electron loss (to simplify-carbon dioxide). The entire man-made environment contributes to the excessive Positive Ions count: air conditioning, building and furniture materials, electromagnetic fields, fluorescent lights, carpet, metal, plastics, chemicals, air pollution etc. Positive Ions can turn into free radicals in the body which can damage cell metabolism, mitochondria dysfunction and increase the acidity. This is because they oxidize the cells, raising the levels of lactic acid which cause fatigue, low energy, low 
immunity, infections, autoimmune, inflammatory, tumor and many other diseases.

\section{Negative Ions Are the Best Treatment for Decreased Oxygen Utilization}

The key to health is to maximize oxygen utilization by eliminating or decreasing the effect of the Positive Ions.

The best treatment for Decreased Oxygen Utilization is the use of the Negative Ions [1]. The massive discharge of Negative Ions secreted during thunderstorm/rain and around waterfalls. Negative Ions are the atoms or molecules which are created by an electron gain. Amazing force of nature with Negative Ions, the God's gift, provide with a feeling of well-being, neutralize free radicals and prevent oxidation, improve all the body's natural biological

\section{Table 1.}

functions such as improving cell metabolism, immunity, digestion, purifying body, balancing the nervous system, better sleep, relieve asthma, allergy and other respiratory disorders, lower blood pressure, natural painkiller, with anti-stress, anti-anxiety, antidepression effects [2,3]. Negative Ions increase the flow of oxygen to the brain resulting in higher alertness, decreased drowsiness and more mental energy, better memory, intellectual capacity [4].

\section{Negative and positive ions and their effects on human body}

Negative ions have the effect to restore the shape of the red cells allowing them to flow through the tiny holes, vessels. (Figures $2 \&$ 3) Negative Ions separate red cells from each other and prevent the formation of blood clots, increasing their oxygen carrying capacity. The thick blood (damaged and agglutinated red cells due to positive ions) can't flow through the tiny vessels (Tables $1 \& 2$ ).

\begin{tabular}{|c|c|}
\hline NEGATIVE IONS & POSITIVE IONS \\
\hline Thunderstorm, rain & Air Conditioning \\
\hline Waterfalls & Airport, Aircraft \\
\hline Sea & Air pollution \\
\hline River & Mall, Commercial Centers \\
\hline Mountains & Metro \\
\hline Forest & Building materials, chemical, toxic, painting \\
\hline Park & Furniture Materials \\
\hline Negative Ion Generator / Ionizer Air purifier with Negative Ions & $\begin{array}{l}\text { Electrical Devices: TV, radio, fridge, light, signboard, microwave, washing } \\
\text { machine etc }\end{array}$ \\
\hline Negative Ions Bed and Mattress & Electronic devices: mobile, Wifi, laptop, video camera, radar \\
\hline Negative Ions Clothes & Smoking \\
\hline Negative Ions (Anion) Sanitary Napkins & Alcohol \\
\hline Energy Stone with Negative Ions & Unhealthy food (fast food, fried food, canned food, carbohydrates, sweet) \\
\hline Shower with Negative Ions & Lack of sleep, sleeping in closed spaces \\
\hline Himalayan Rock Last Lamp & Underground, cave \\
\hline Himalayan Rock Salt & Construction site \\
\hline Alkaline water with Negative Ions & Confined spaces \\
\hline Negative Ions USB Key and Charger & Office \\
\hline Negative Ions bracelet & Night clubs, Bars \\
\hline Negative Ion Waist Belt & Medications and Treatment (some) \\
\hline
\end{tabular}

\section{Table 2.}

\begin{tabular}{|l|l|l|}
\hline Environment & Anion $\left(/ \mathrm{cm}^{3}\right)$ & Relation \\
\hline Forests \& waterfalls & $>10000$ & Cure disease \\
\hline Alpines \& Sea sides & $2000-10000$ & Against disease \\
\hline Parks of cities & $500-1000$ & Keep healthy needs \\
\hline Houses of cities & $40-100$ & Cause some diseases \\
\hline Air conditioning & $0-25$ & Disease can flourish \\
\hline
\end{tabular}

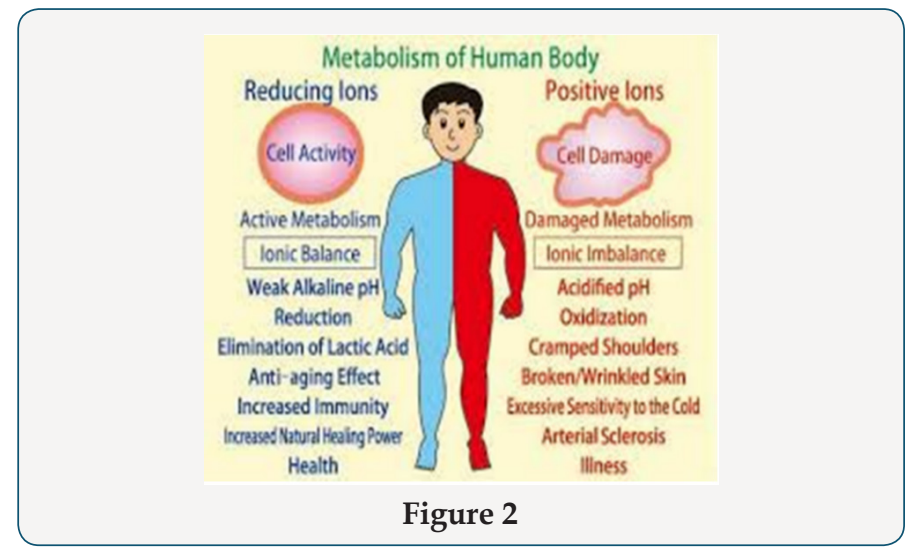




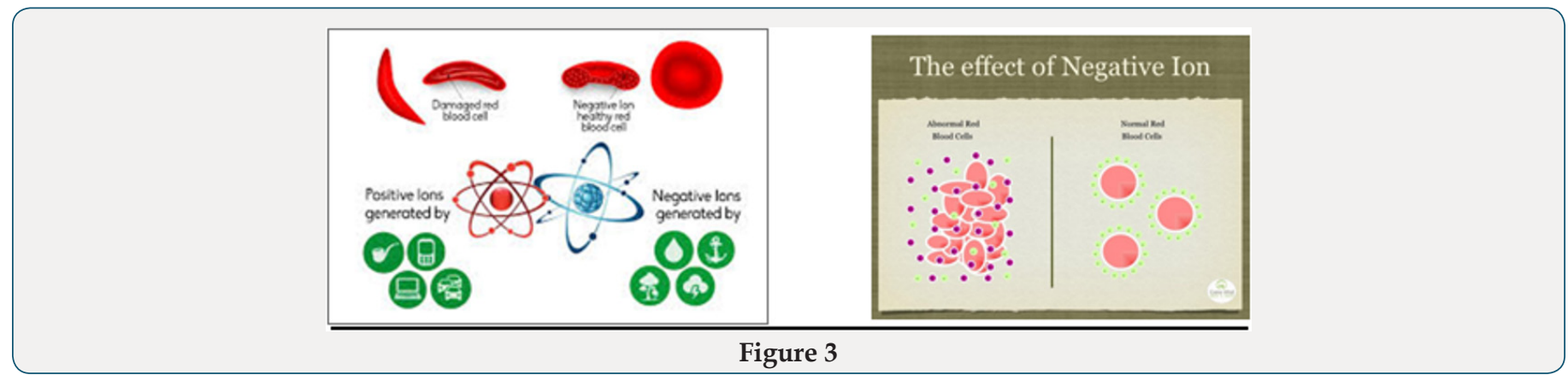

Negative Ions: Have miraculous effects on all diseases, while Medicine is powerless, and when the diseases are caused by Jinn, they help to diagnose and remove the Evil of Satan as the Jinn, being composed by more Positive Ions, do not like the Negative Ions. "(Remember) when He overwhelmed you with drowsiness [giving] security from Him and sent down upon you from the sky, rain by which to purify you and remove from you the evil (suggestions) of Satan and to make steadfast your hearts and plant firmly thereby your feet." (Quran, Al-Anfal 8:11) The doctors can only treat symptoms, but the cure is only from our Creator (Ruqya, Negative Ions, Dua etc), so the best doctors really caring about themselves and their patients should learn curative treatment for their own benefits (Allah's rewards) and for patients' safety and cure. "And when I am ill, it is He who cures me." (Quran, Ash-Shuara 26:80).

\section{DISEASES CAUSED BY JINN}

The unseen World of Jinn was clearly explained in Quran and Hadith. The interpenetration and interaction of the Jinn into mankind are on rise and Satan is our real enemy creating multiples problems and health issues and the main purpose of the Satan is to bring maximum people to the Hellfire. The Arabic word "Jinn" comes from the verb "Janna" which means to hide. Shaytan (Satan, Demon, Evil Jinn, Devil) is a name given to disbelieving Jinni. Allah said: "And the jinn We created before from scorching fire." (Quran, Al Hijr 15:27) "And I did not create the jinn and mankind except to worship Me." (Quran, Adh-Dhariyat 51:56) "And He created the jinn from a smokeless flame of fire." (Quran, Ar-Rahman 55:15) The Jinn can take a variety of physical forms which human may see and converse with: humans, human-animals, animals, snakes, scorpions, black dogs, black cats etc. [5]. "Researching the topic of the Jinn is one of the most difficult of subjects, especially since it has to do with finding out about a hidden world that is not visible and cannot be measured in physical or empirical terms." [6] The Sheikh of Islam Ibn Taymiyyah said: "What he (Imam Ahmad) said is self-evident. The Jinn may possess someone and cause them to speak a language he does not even know. A possessed person may be violently beaten, in a way that even a camel may not endure, yet he neither feels the beating nor is aware of the words he says." Furthermore, the possessed person may drag a non-possessed person and or the mat he is sitting on, moves things from a place to another and other practices that confirmed to those who witnessed such behavior that the one who spoke or moved was not a human being. [5]

The Characteristics of the Jinn comparing with mankind presented in (Tables 3-12)
Table 3.

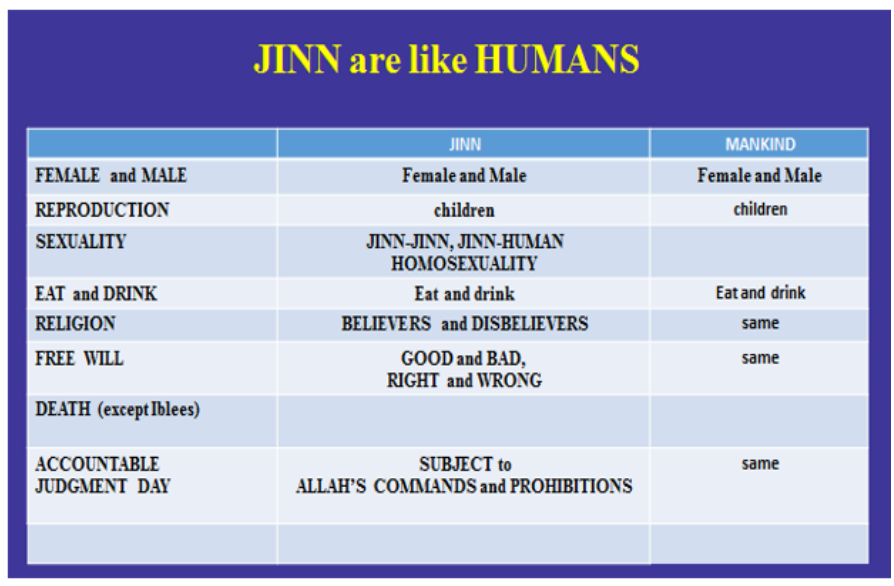

Table 4.

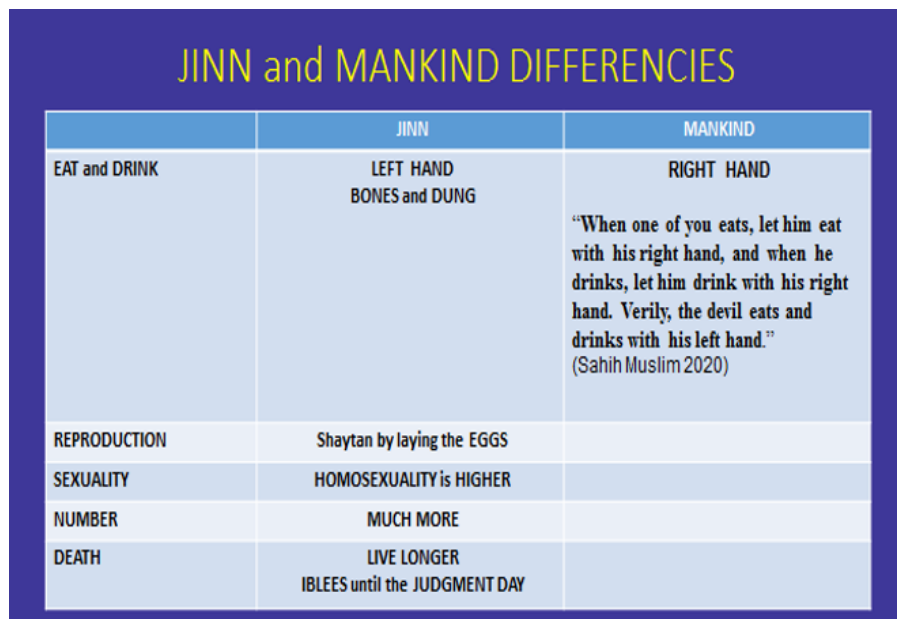

Table 5.

\begin{tabular}{|c|c|c|}
\hline & JINN & MANKIND \\
\hline EAT and DRINK & $\begin{array}{c}\text { LEFT HAND } \\
\text { BONES and DUNG }\end{array}$ & $\begin{array}{l}\text { RIGHT HAND } \\
\text { "When one of you eats, let him eat } \\
\text { with his right hand, and when he } \\
\text { drinks, let him drink with his right } \\
\text { hand. Verily, the deril eats and } \\
\text { drinks with his left hand." } \\
\text { (Sahih Muslim 2020) }\end{array}$ \\
\hline REPRODUCTION & Shaytan by laying the EGGS & \\
\hline SEXUALITY & HOMOSEXUALITY is HIGHER & \\
\hline NUMBER & MUCH MORE & \\
\hline DEATH & $\begin{array}{l}\text { UVE LONGER } \\
\text { IBLEES until the JUDGMENT DAY }\end{array}$ & \\
\hline
\end{tabular}


Table 6.

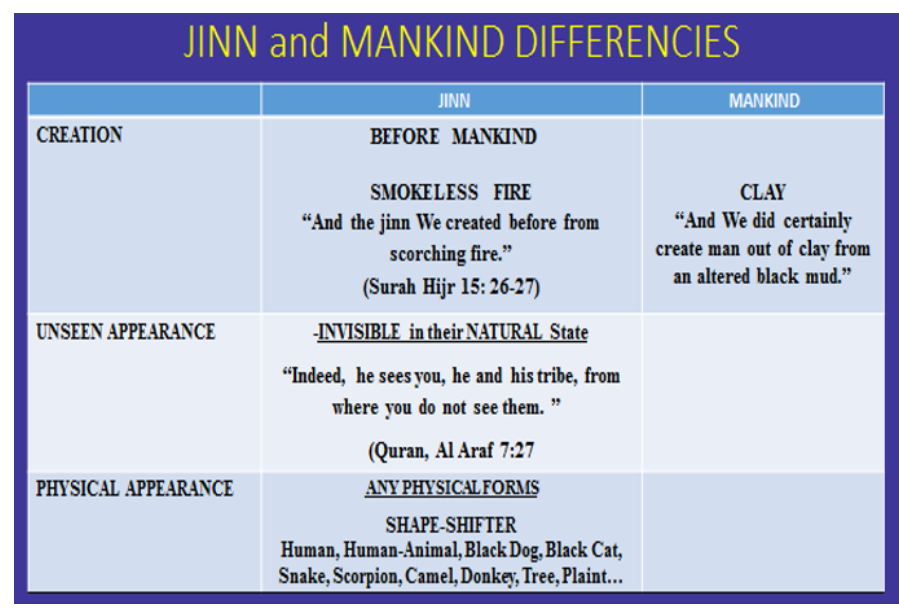

Table 7.

\begin{tabular}{|c|c|c|}
\hline \multicolumn{3}{|c|}{ JINN and MANKIND DIFFERENCIES } \\
\hline & JINN & $\begin{array}{l}\text { MANKIND } \\
\end{array}$ \\
\hline PHYSICAL LOOKING & $\begin{array}{l}\text { Ugly, Unpleasant, Repulsive-looking, scary, } \\
\text { The branches of Zaggoom (a tree in Hell) is } \\
\text { compared in the Quran to the heads of devils: } \\
\text { "Verily, it is a tree that springs out of the bottom of } \\
\text { Hell-Fire. The shoots of its fruit-stalks are like the } \\
\text { heads of devils"(Quran 37:64-65). }\end{array}$ & \\
\hline $\begin{array}{l}\text { DISBELIEVING JNN } \\
\text { CHARACTERISTICS }\end{array}$ & $\begin{array}{l}\text { Arrogance, rebellious, pride, harsh, malevolent, } \\
\text { disobedient, malicious, stubborn, liar, pledger, } \\
\text { jealous, hypocrite, deceiving, mischief-maker, } \\
\text { vengeful, harmful, disturbing, aggressive, } \\
\text { spoiling our thoughts and hearts with the evil } \\
\text { inclinations }\end{array}$ & \\
\hline
\end{tabular}

\section{Table 8.}

\begin{tabular}{|c|c|c|}
\hline \multicolumn{3}{|c|}{ JINN and MANKIND DIFFERENCIES } \\
\hline & JINN & MANKIND \\
\hline \multirow{5}{*}{ PLACE of LIVING } & $\begin{array}{l}\text { QAREEN } \\
\text { "Everyone of you has been assigned a companion from } \\
\text { the Jinn." }\end{array}$ & QAREEN \\
\hline & $\begin{array}{l}\text { "Verily, Satan flows through the human being } \\
\text { like blood." (Sahih Muslim 2174) }\end{array}$ & \\
\hline & $\begin{array}{l}\text { "There are Shayateen among the Jinn and Shayateen } \\
\text { among mankind, who inspire each other." (Quran 6:112) }\end{array}$ & \\
\hline & EVERYWHERE & \\
\hline & $\begin{array}{l}\text { Dirty Places: toilet, garbage, animal yard, graveyard, } \\
\text { cave, old ruins, market, money transaction places } \\
\text { desert, under the tree, mountain, between shadow/sun }\end{array}$ & \\
\hline
\end{tabular}

\section{Table 9.}

\begin{tabular}{|l|l|l|}
\hline \multicolumn{2}{|l}{ JINN and MANKIND DIFFERENCIES } \\
\hline \begin{tabular}{l|l|}
\hline SUPERNATURAL \\
POWER
\end{tabular} & $\begin{array}{l}\text {-Fly with Light speed } \\
\text { (travel around the World in a blink of eye) }\end{array}$ \\
& -"Shape-shift" (invisible-visible) \\
& $\begin{array}{l}\text {-Illusion Creation (halal-haram, right-wrong, trust-mistrust, } \\
\text { certainty-suspicion, sureness-doubt, small-big, beautiful-ugly, } \\
\text { appear-disappear, fixed-movable, far-close, one thing is } \\
\text { replaced by another etc) }\end{array}$ \\
& -Stronger (can move heavy things in a second) \\
& -Possess and trouble humans with no or weak faith: \\
& Jinn possession, Black Magic, Evil Eye \\
\hline
\end{tabular}

Table 10.

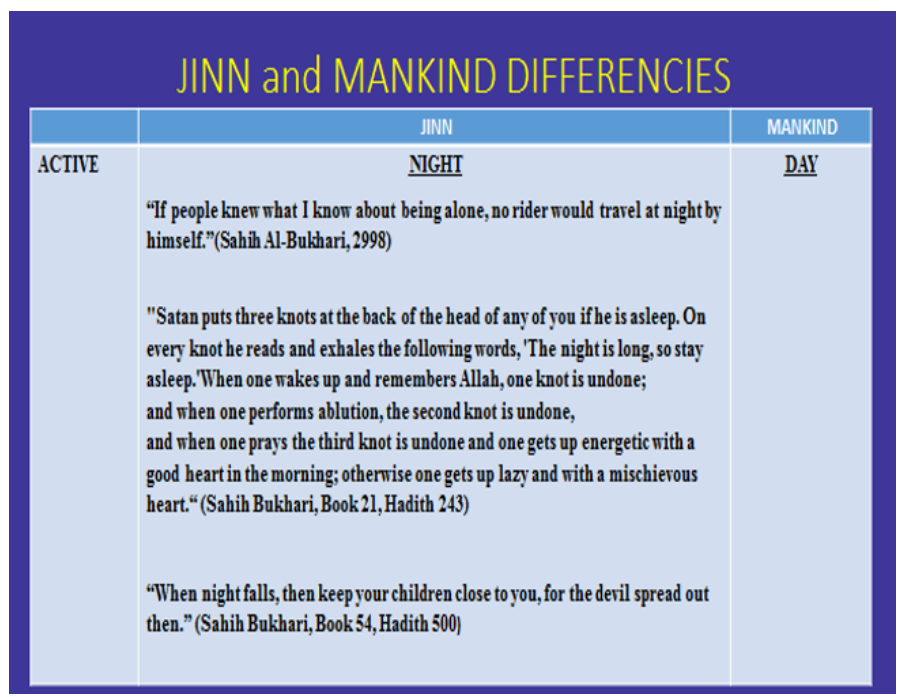

\section{Table 11.}

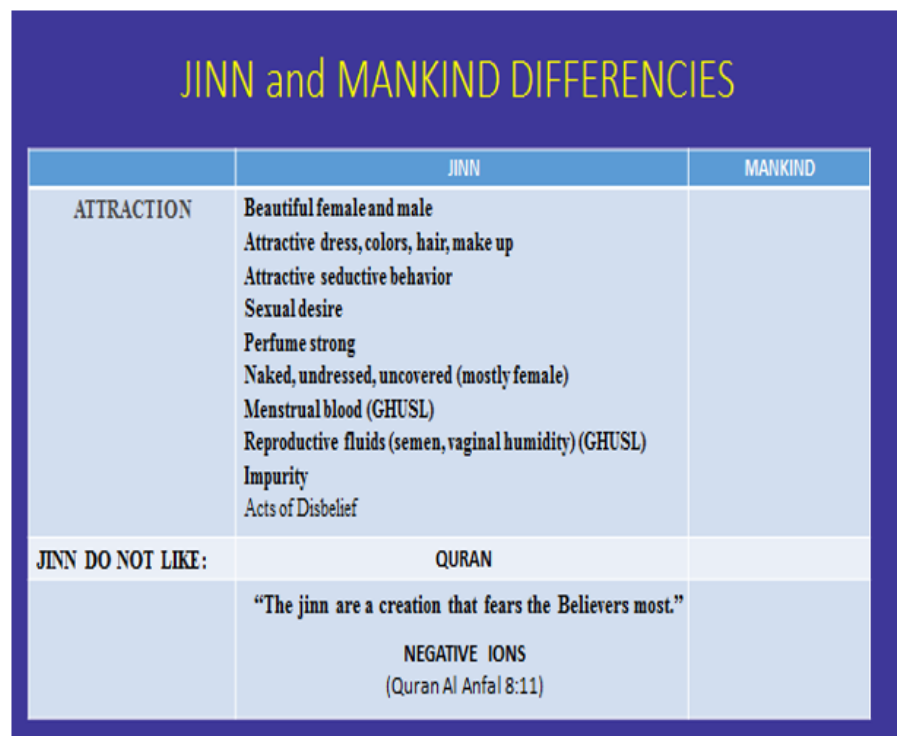

Table 12.

\begin{tabular}{|c|c|c|}
\hline & JINN & MANKIND \\
\hline $\begin{array}{l}\text { SHAYTAN } \\
\text { PURPOSE }\end{array}$ & $\begin{array}{l}\text { To bring maximum people to the Hellfire } \\
\text { "(thlees) said: 'Because You hare sent me astray, surely I will sit } \\
\text { in } \\
\text { mait against them (human beings) on Your Straight Path. } \\
\text { Then I will come to them from before them and behind them, } \\
\text { from their right and from their left, and You will not find most of } \\
\text { them grateful to You" (Quran, Al-A'raaf 7:16-17) }\end{array}$ & $\begin{array}{l}\text { SHAYTAN is a TEST } \\
\text { "0 you who hare beliered, } \\
\text { enter into Islam completely } \\
\text { [and perfectly] and } \\
\text { do not follow the footsteps of } \\
\text { Satan. Indeed, he is to you a } \\
\text { clear enemy." } \\
\text { (Quran, Al Baqara 2:208) }\end{array}$ \\
\hline NOPOWER & $\begin{array}{l}\text { "Indeed, over My [believing] servants there is for you } \\
\text { no authority. And sufficient is your Lord as Disposer } \\
\text { of affairs." (Quran, Al Isra 17:65). }\end{array}$ & \\
\hline
\end{tabular}

Ibn Taymiyyah (may Allah have mercy on him) said: "The possession of man by Jinn can be out of sexual desire, evil notions, or even love just as it is with humans which is Fahsha'a, i.e. immorality and bad conduct which is forbidden. There is time that a person 
who has been possessed out of love, this type is less difficult as others, such as revenge by possession, or by pouring hot water or killing them without knowing, and this is the most difficult type of possession. What this means, Allahu Alim, is that the possession of a Jinn who is taking a revenge is different to the one who possesses for love, they are not trying to kill them, they just want to be with them, even though they can cause them a lot of harm by making them ill, or not appear nice. These are tricking the Jinn do so that the person is just theirs, but when it is revenge they are trying to kill the individual." [5] Jinn diseases are created via Black Magic, Jinn Possession and Evil Eye.

\section{BLACK MAGIC - WITCHCRAFT - SIHR}

Ibn Quddama Al-Maqdisi in Al-Mughni stating: "Sihr is a set of uqad (knots), ruqa (incantations), and words uttered or written, or carried out in such a way as to affect the body of the subject (almashur), his heart and mind, without even coming into contact with him/her. The reality of Sihr is that there are some types that can kill, cause one to fall ill, or act as an obstacle against a man having sexual intercourse with his wife. Other types can separate spouses and can make them hate or love each other." (Shark Al-Qurtubi 'Ala Saheeh Muslim, 6/6) [7]. According Imam Abdul-Aziz Ibn Baz: "Sihr or Sorcery as defined by Islamic law consists of charms or incantations that are composed to cause illness, loss of mental stability, death, to separate spouses from each other, or to prevent a man from acts of intimacy with his wife..." [8] Shumar said: Ibn 'A'ishah said: "Sihr is so called in Arabic because it changes health to sickness". AlQurtubi said: "Witchcraft is a profession based on trickery". The one who wants witchcraft performed goes to the witch and asks him to perform witchcraft on someone. Or he may think that this person is not a witch, so he asks him to treat him or one of his relatives for some sickness or ask to resolve some problem, to protect or to pray for someone. The Jinn's supernatural powers: flying with light speed, ability to "shape-shift" (passing from invisible to physical forms), moving heavy things in a second, creating the illusions and possessing the mind and body of other creatures; have been used by Fortune-tellers even before Islam. Voodoo, Tarot, Poltergeists, Witchcraft, Astrology, Horoscope, Palm-Coffee-Tea Leaves reading, Clairvoyant, Spaewife, Soothsayer, Medium, Zar Zar dance: all these involve the Jinn.

The effects of the Jinn are not just limited to Fortune-tellers. The activities such as oujia boards and séances, used to contact the dead, are manipulated by the Jinn. Other biggest manipulations of the Jinn are through visions and voices. Fortune telling by "reading" or "spiritual consultation", give the client advice and predictions which are said to have come from spirits or in visions. Contract is signed between the Fortune teller and Shaytan in order to target the person or family or materialistic object etc. The servant Jinn operate with the Qareen, the Jinn attached to every human being since his birth. It is this Qareen which whispers to our base desires and constantly tries to divert us from righteousness. The Prophet (pbuh) said: "Every one of you has been assigned a companion from the Jinn. (Muslim - Eng. Trans. Vol.4, p.1472, No.6757) Qareen communicates with the servant Jinn informing about everything in the past and somehow future if something was already finalized (travel tickets etc.) The servant Jinn inform the Fortune teller, so people without knowledge will be amazed and will trust the Fortune teller knowing the past and somehow the future.

\section{Male Sexual Disorders by Black Magic}

Wahid Ibn Abdelssalam Bali describes Black Magic on the sexual functions, Infertility [7].

\section{Sihr Ar-Rabt (Penile Erection Problems)}

Ar-Rabt is the inability of a physically fit and healthy man to have sexual intercourse with his wife. How Sihr Ar-Rabt is done? The Jinn entrusted with the task of sihr settles in the man's brain and precisely in the centre of sexual excitement which sends codes to the sexual organs; and lets the sexual organs function normally. But when a man approaches his wife, with the intention having sexual intercourse, the Jinn thwart the centre of sexual excitement and blocks the signals sent to the organs which pump blood into the penis for erection. Consequently, the blood drawbacks rapidly from the penis and the penis shrinks. A man affected by this sihr feels active, energetic about having sexual intercourse and his penis is even erected as long as he is distant from his wife. Nevertheless, as he approaches her, when he is about to penetrate, his penis shrinks, so he cannot have the intercourse; and the erection is essential ingredient in achieving sexual intercourse.

\section{Sihr Al-Ajz Al-Jinsi (Sexual Inability/Impotence)}

Man is unable to have sexual intercourse with his wife, whether he is distant from or near her, as his penis cannot erect.

\section{Sihr Adh-Dhuf Al-Jinsi (Sexual Weakness)}

A man can only have sexual intercourse with his wife after long periods. Sexual intercourse takes place for only short time, after which the penis loses its rigidity.

\section{Premature Ejaculation}

Premature ejaculation can be caused by excitement triggered by Jinn within prostate gland.

\section{Idiopathic Male Infertility Caused by Black Magic}

Idiopathic Male Infertility is caused by Jinn. Jinn may interfere with one of the testicles by pressing it or by other means; so that the testicle would not produce the required sperm count to fertilize the oocyte. As the sperm travel, seminal fluid is added from the seminal vesicles, prostate, testis and epididymis and periurethral glands. The function of the ejaculate is to transport sperm into the female genital tract and to provide a suitable environment for sperm survival during this transit. An adequate volume of ejaculate is required to carry the male gametes into the female reproductive tract, and thus ejaculate volume is an important component of a semen analysis done to investigate Male Infertility. The seminal fluid acts as the nourishment for the spermatozoids. The Jinn interferes in this process by preventing the glands from secreting the seminal fluid. As the result of this satanic interference, the spermatozoids die.

In the case of Infertility caused by Sihr the following symptoms may occur: 
a. Chest tightening which begins at Al Asr and may last until midnight
b. Absentmindedness
c. Nightmares
d. Anxiety during sleep
e. Lower back pain

There are many other Black Magic symptoms [5]. The brain is the main regulator of the body. Every human organ has a control center in the brain, from which it receives codes. "And indeed, they knew that the buyers of it (magic) would have no share in the Hereafter. And how bad indeed was that for which they sold their own selves, if they but knew." (Quran, Al Baqarah 2:102) The Prophet (pbuh) said: "The prescribed punishment for the magician is that he be executed by the sword" (Authentic, Tirmidhi).

\section{JINN POSSESSION}

Allah The Almighty has given to Jinn the ability to dwell inside human beings, but this can only happen by His permission, Glory be to Him (Table 13).

\section{Table 13.}

\begin{tabular}{|c|c|c|}
\hline \multicolumn{3}{|r|}{ JINN POSSESSION REASONS } \\
\hline 1 & DESIRE & $\begin{array}{l}\text { DESIRE OF POIVER } \\
\text { DESIRE OF CONTROL (CONTROL OF LIFE) } \\
\text { ATTRACTION/LOVE }\end{array}$ \\
\hline 2 & REVENGE & $\begin{array}{l}\text { WHEN THE PERSON COULD UNINTENTIONALLY HARII JNN } \\
\text { (THROWING HOT WATER, STONE,URINATING, JUMPING OREVEN } \\
\text { KILLING) }\end{array}$ \\
\hline 3 & $\begin{array}{l}\text { JNNISEVIL AND SIIPLY } \\
\text { WANT TOHARM }\end{array}$ & MIISCHIEF, CREATE CONFUSION,DISCOMFORT,HARII \\
\hline 4 & MISGUIDANCE & IDOL.ATRY, ACTS OF DISBELIEF \\
\hline 5 & RIBA & $\begin{array}{l}\text { "Those who consume interest cannot stand [on the Day of } \\
\text { Resurrection] except as one stands who is being beaten by } \\
\text { Satan into insanity." (Quran, Al Baqarah 2:275) }\end{array}$ \\
\hline 6 & $\begin{array}{l}\text { TURNING AWAY FROM THE } \\
\text { REMEMBRANCE OF ALLAH }\end{array}$ & $\begin{array}{l}\text { "And whoever is blinded from remembrance of the Most } \\
\text { Merciful - We appoint for him a devil, and he is to him a } \\
\text { companion." (Quran, Al Zukhruf 43:36) }\end{array}$ \\
\hline 7 & BLACK MAGIC & JNN SENT BY BLACK MLAGIC \\
\hline
\end{tabular}

\section{Jinn Possession Signs and Symptoms}

The doctors should learn the sign and symptoms of the Jinn Possession to diagnose the cause of the disease to manage properly as the medications will not work on the Jinn:

i. Reaction to Quran (turning away and reacting strongly when hearing Quran or Azhan (call for the prayer); fainting, seizure, headache, screaming, the Jinn may speak when Quran is recited

ii. Reaction to the Negative Ions Treatment (sudden change of the behavior, aggression, refusal or removal of the Negative Ions products. These two symptoms are the most important to diagnose the presence of the Shaytan and they are associated to many other symptoms like

iii. Headache with unknown cause iv. Erratic behavior in one's words, deeds and movements

v. Nightmares

For other Jinn Possession symptoms please refer to $[5,6,9,10]$

\section{Evil Eye}

Evil Eye is like an arrow which comes from the soul of the one who envies towards the one who is envied and on whom the Evil Eye is put; sometimes it hits him and sometimes it misses. If the target is exposed and unprotected, it will affect him but if the target is cautious and armed the arrow will have no effect and may even come back on the one who launched it. $[8,9]$ The Evil Eye is an illness which some people (not everyone) carry. It entails looking at a blessing which someone has within them or from that which they possess from worldly possessions with amazement or liking it. This then leads to dwelling on the matter, continually looking at the person who has the thing which he feels jealous towards and subsequently leading to an attack described as rays emitting from a person's eyes (and their soul) and subsequently affecting him physically/ mentally causing him to become ill and even die.

One doesn't need to physically look at someone to give him the Evil Eye; even a blind person can give the Evil Eye. One can even give the Evil Eye merely by listening to the description of a person's blessings. [1] Everyone who gives the Evil Eye is jealous but not every jealous person gives the Evil Eye.The evidence for this is that Ayn (Evil Eye in Arabic) can even be given to yourself, your own children and even when joking. The Hadith tells: "Whoever among you sees something in himself or in his possessions or in his brother that he likes, let him pray for blessings for it because the Evil Eye is real." (Ibn al-Sunni in A'mal al-Yawm wal-Laylah, page 168; Al-Haakim, 4/216. Classed as Sahih by al-Albaani in Al-Kalim at-Tayyib, page 243) This Hadith explains that a person may harm himself, his wealth, his children, his wife etc by the Evil Eye. "The Evil Eye is real and can bring down a person from a high mountain." (Sahih al Jami' 4146). "The Evil Eye can take a person into grave and takes the camel into the cooking pot." (Narrated by Jabir Bin Abdullah).

Hasad (destructive jealousy) causes a great deal of harm. Narrated from Az-Zubayr ibn al-A'waam (may Allah be pleased with him), the Prophet (pbuh) said: "There has come to you a disease of the nations before you, jealousy and hatred. This is the 'shaver' (destroyer); I do not say that it shaves hair but that it shaves (destroys) faith. By the One in Whose Hand is my soul, you will not enter Paradise until you believe, you will not believe until you love one another. Shall I not tell you of that which will strengthen love between you? Spread the greetings of peace amongst yourselves." (Tirmidhi, 2434) Narrated from Abdullah ibn Abbas (may Allah be pleased with him), the Messenger of Allah (pbuh) said: "The influence of the Evil Eye is a fact. If anything were to precede the divine decree it would have been the influence of an Evil Eye. Therefore, when you are asked to take a bath (as a cure) from the influence of the Evil Eye, you should take a bath.' (Muslim, 5427) Narrated by Abu Hurairah (may Allah be pleased with him) said: The Messenger of Allah (pbuh) said: “My nation will be stricken with 
the disease of the other nations." They said: "What is the disease of the other nations?" He said: "Insolence, arrogance, accumulation of wealth, competition in worldly gains, mutual hatred and envy until there will be wrongdoing and then killing." (Al Tabaraani in Al-Awsat; Ibn Abi'l-Dunya)

For the Evil Eye signs and symptoms to refer to $[8,9,11]$.

\section{Negative Ions Treatment}

Hippocrates was the first to proclaim, "the healing power of nature.” Allah, The Most Merciful, The Highest, “...sent down upon you from the sky, rain by which to purify you and remove from you the evil [suggestions] of Satan and to make steadfast your hearts and plant firmly thereby your feet." (Quran Al Anfal 8:11). Rain contains high concentration of Negative Ions. From this great Quranic verse, we understand that Evil Jinn are composed of more Positive Ions. Here are the cases cured by Negative Ions by Allah's will:

\section{CASE 1: Urinary Tract Infection, resistant to the} Antibiotherapy, was cured by Negative Ions

A young lady presented to me with Urinary Tract Infection for one year, with pain on urination, urgency, frequency, causing to urge to urinate every fifteen minutes. She was looking for toilet locations limiting her activities and with impossibility to travel being attached to toilet. She tried different antibiotics by different doctors. When I checked for the most frequent infections which can cause urinary symptoms, Ureaplasma Urealyticum and Mycoplasma Genitalium were found but they were resistant to all antibiotics proving low immunity and wrong previous management. I suggested Negative Ions (Anion Napkins containing 6000 units of Anion/cm3 and Energy stone) as Medicine was powerless anyway. Two weeks later, a miracle happened, Mycoplasma disappeared and Ureaplasma became positive to half of antibiotics just by using Negative Ions. She went back to her previous normal life.

\section{CASE 2: Miraculous effects of Negative Ions on the Male Infertility}

$\underline{\text { Table } 14}$.

\begin{tabular}{|c|c|c|c|c|c|}
\hline Semen & \multicolumn{4}{|c|}{ Before Negative Ions } & $\begin{array}{c}\text { Only one month } \\
\text { Negative ions }\end{array}$ \\
\hline Volume ml & 2 & 1.5 & 1 & 0.8 & 1.5 \\
\hline Liquefaction & $\begin{array}{c}>120 \\
\text { min }\end{array}$ & 60 & 60 & 60 & $<30$ min \\
\hline Viscosity & high & high & high & high & normal \\
\hline Count mln/ml & 5 & 8 & 25 & 48 & 16 \\
\hline $\begin{array}{c}\text { Motility (a+b) } \\
\%\end{array}$ & 0 & 0 & 2 & 0 & 25 \\
\hline $\begin{array}{c}\text { Typical } \\
\text { forms\% }\end{array}$ & 10 & 30 & 70 & 1 & 95 \\
\hline
\end{tabular}

Young couple with Primary Infertility due to the Male factor with one unsuccessful IVF came to see me for another IVF. But I suggested the Negative Ions to improve the semen quality. Male Infertility, due to delayed liquefaction, high viscosity, with all immotile spermatozoids, improved miraculously after using only one-month Negative ions (Energy stone, Anion napkins and going to the sea). Before Negative Ions he was using medications to improve semen quality, controlling hydration and food with no effects (Table 14).

\section{CASES 3 and 4. Two Cases of Prostatitis cured by Negative Ions}

Two men, husbands of my two patients, were having prostatitis. They have used different treatments, but the discomfort was persisting. With Negative Ions (Energy stone and Anion napkins), the symptoms disappeared.

The Negative Ions products (Ionbox 20 million Negative Ions, Negative Ions (Anion) napkins, Negative Ions bed, clothes, other products) should be used to diagnose and treat the diseases as the Negative Ions act in two ways: putting the body in alkaline and removing Satan.

\section{Ruqya Treatment}

Ibn Al-Qayyim Al-Jawziyya (May Allah have mercy on him) said: "Whoever abandons the Quran would abandon treating sickness and seeking healing through it-i.e., the Quran." (Al-Fawaa'id Ibn Qayyim, p.156). "The Quran is the most complete cure from all physical and psychological illnesses - the illnesses of this World and the illnesses of the Hereafter. Not everyone is capable, nor is everyone given the success from Allah to seek a cure from it. If the sick person uses the proper method of using the Quran as a medicine, with belief complete faith and acceptance, and firm belief in it as a cure, and he fulfills all the conditions [of doing so], no disease will ever overcome him. How can a disease overcome the speech of the Lord of the Heavens and the Earth, the speech which if it was sent upon a mountain, would render that mountain to dust. The speech that if it was sent upon the Earth, would break the Earth into pieces? There is no illness of the heart and the body except that the Quran contains the means to guide how to cure it, why it happens, and how to protect from it, for those whom Allah gives the understanding of his book. As for the diseases of the heart, Allah mentions them in detail along with their causes and the method of curing them. So, the one who is not cured by the Quran, may Allah not cure him, and the one who the Quran is not sufficient for him, May Allah not suffice him in anything! It is known that certain things that we say have particular special qualities and proven benefits, then what do you think of the speech of the Lord of the Worlds, the one who the virtue of his speech over the speech of others, is like the virtue of Him over his creation. The Quran is the perfect cure, and it is a beneficial means of protection, and a guiding light and a general mercy. If it was sent upon a mountain it would render it asunder from its greatness and its glory."

Anas (may Allah have mercy on him) narrated that: "The Messenger of Allah (pbuh) said "Help your brother whether he is a wrongdoer or has been wronged." I said: "O Messenger of Allah, we know how to help him if he has been wronged, but how can we help him if he is wrongdoer?" He said: "Stop him from doing wrong. That is how you help him." Expelling the jinn is also relieving the distress of the one who has been wronged. Abu Hurairah (may Allah have mercy on him) narrated that the Prophet (pbuh) said: "Whoever 
relieves a believer of some worldly distress, Allah will relieve him of some of the distress of the Day of Resurrection, and whoever conceals (the faults of) a Muslim, Allah will conceal him (his faults) in this World and the Day of Resurrection. And whoever relieves the burden from a destitute person, Allah will relieve him in this World and the next. Allah will help His slave so long as His slave helps his brother. Whoever follows a path in pursuit of knowledge, Allah will make easy for him a path to Paradise. No people gather in one of the houses of Allah, reciting the Book of Allah and teaching it to one another, but the angels will surround them, tranquility will descend upon them, mercy will envelop them, Allah will mention them to those who are with Him. And whoever is hindered because of his bad deeds, his lineage will be of no avail to him." (Engl Ref, Vol. 1, Book 1, Hadith 225) Abu Bakr as-Siddiq visited A'isha while she had a (health) complaint and a Jewish woman was making incantation (ruqya) for her. Abu Bakr said, "Do it (incantation) with the Book of Allah.” (Engl. Ref: Book 50, Hadith 11)

"There is no true God except Allah. He is One and He has no partner with Him; His is the sovereignty and His is the praise, and He is Omnipotent"- "La ilaha illallahu, wahdahu la sharika lahu, lahul-mulku wa lahul-hamdu, wa Huwa 'ala kulli sha'in Qadir (Bukhari, Muslim, Engl ref: Book 16, Hadith 1410) Manipulations with "successful" exorcism cases are done in the West and in the East calling upon Jesus (human) or idols or other religions rather than Allah the Almighty. In the reality, these non-Islamic exorcists are committing the shirk, associating partner with Allah, consolidate people's kufr (disbelief) and shirk and make them firm in their path towards Hellfire, which is Shaytan's goal for humanity. Unknowledgeable possessed person thinks and believes that the Satan has left in the name of Jesus. The Satan has achieved the goal of misguiding people and has left as the job was done. Dr Bilal Philips described in his book "Exorcism tradition in Islam" seventeen cases [12]. It is very important that everybody learns "Simple guide to Self Ruqya", done by Muhammad Tim Humble, my teacher [13].

Case of Prostate Adenoma, causing frequent urination, improved with Ruqya

72 y-old man, my family member, presenting the prostate adenoma, was suffering from the frequent urination every hour and other symptoms. His wife, unknowledgeable, was going to the Fortune teller for about 30 years with good intention asking the Fortune teller to pray for her family. As a result, almost all members of the family are under the effects of Black Magic. After one month of Ruqya twice per day done together, by me and him, he didn't urinate six hours; all praise is due to Allah.

\section{PROTECTION \& PRECAUTIONS AGAINST SHAYTAN}

Because the Jinn can see us while we cannot see them, the Prophet Muhammad (pbuh) taught us many ways to protect ourselves from their harm.

\section{Perform five obligatory prayers daily (the best Medicine) and night prayers}

“... And the most excellent prayer after what is prescribed is prayer during the night." (Muslim 6: 2661). Said Ibn Mansur (may Allah have mercy on him) reported: "Ibn Umar (may Allah have mercy on him) said: "Not a man wakes up in the morning without having observed salatul Witr, but that a rope measuring approximately seventy cubits will be put over his head in the morning (According to Al-Hafiz, a very good chain of transmission (Fath: 3/25)

\section{Dua related to the sickness and protection from the Jinn (duas.com):}

Dua of the Prophet Ayyub (May Allah have mercy upon him): "Indeed, adversity has seized me, and you are the Most Merciful of all those who show mercy"

Dua of the Prophet Yunus (May Allah have mercy upon him) when he was in the belly of the whale: "There is no deity worthy of worship but You, glory to be to You, Indeed, I have been of the wrongdoers." Dua-Shifa "Adh-hib-il-ba'sa rabba-an-naas, washfi ant-ash-shaafee, laa shifaa'a illaa shifaa'uk, shifaa'an laa yughaadiru saqamaa." "O Allah, Lord of mankind, the One Who relieves hardship, grant healing, for there is no healer but You, a healing that leaves no trace of sickness." (Bukhari, 5750 and Muslim, 2191).

-Dua of the Prophet (pbuh) used to seek Refuge with Allah for Al-Hasan and Al-Husain and say: "Your forefather (i.e. Abraham) used to seek Refuge with Allah for Ishmael and Isaac by reciting the following: "O Allah! I seek Refuge with Your Perfect Words from every devil and every poisonous reptile, and from every bad eye." (Bukhari 3371) -Dua Jibril (Gabriel) came to the Prophet (pbuh) and said: "O Muhammad (pbuh)! Do you feel sick?" He (pbuh) said, "Yes." Jibril supplicated thus (i.e., he performed Ruqyah): "Bismillahi arqeek, min kulli shay'in yu'dheek, min sharri kulli nafsin aw 'aynin haasid, Allaahu yashfeek, Bismillaahi arqeek." "With the Name of Allah, I recite over you (to cleanse you) from all that troubles you, and from every harmful mischief and from the evil of the eyes of an envier. Allah will cure you; and with the Name of Allah, I recite over you." (Muslim). The messenger of Allah (pbuh) said: 'He who says in the morning and the evening of each day: "In the name of Allah, by whose name nothing can cause harm neither on earth nor in the heaven and He is The All-Hearing, The All-Knowing." (three times), Nothing shall harm him'

\section{Dua in different occasions:}

i. Dua for entering and leaving the toilet

ii. Dua for entering and leaving the house

iii. Dua for setting foot in a new place

iv. Dua for entering and leaving Masjid

v. Dua for new clothes, for dressing and undressing

vi. Dua before eating and after eating

vii. Dua before sexual intercourse

Dua (supplication) is the enemy of calamity; it wards it off and remedies it, prevents it befalling, and relieves it if it has happened. 
Al-Haakim narrated in his Sahih that A'ishah said that the Messenger of Allah (pbuh) said: "Caution is to no avail against the Divine decree and Dua is useful with regard to what has befallen and what has not yet befallen. Calamity may descend and be met by Dua, and they wrestle until the Day of Resurrection". Saying Bismillaah (in the Name of Allah) before entering home, before eating or drinking, and before having intercourse will keep the Shaytan from entering the house or partaking with a person in his food, drink and sexual activity. Similarly, mentioning the name of Allah before entering the toilet or taking off one's clothes will prevent the Jinn from seeing a person's 'awrah (private part) or harming him, as the Prophet (pbuh) said, "To put a barrier that will prevent the Jinn from seeing the 'awrah of the sons of Adam, let any one of you say 'Bismillah' when entering the toilet." (Tirmidhi, 551; Sahih al-Jaami', 3611). The Hadith telling, the Shayateen will stand by the door, when the person comes they listen, if he says Bismillah, Assalaamu 'Alaikum - if he remembers Allah the head Shaytan will say "go back, go back you have no place and no food here." But when you come into the house silent or saying any words other than the remembrance of Allah, He says, 'Ok come here you have a place to sleep you have food come, come" and they come into your house "And say, "My Lord, I seek refuge in You from the incitements of the devils. And I seek refuge in You, my Lord, lest they be present with me." (Quran Al Mu'minun 23:97-98)

\section{Protection from the Satan before and after the intercourse}

It is narrated from Imam as-Sadiq (may Allah be pleased with him): "Whenever a person makes love to his wife, Satan is present. Then, if the name of Allah is remembered, Satan goes far from there, but if the act occurs and the name of Allah is not taken, Satan takes part in that he is one with the sperm". After the intercourse the total body purification, Ghusl, is obligatory as Jinn is attracted by the semen and vaginal humidity.

\section{Make wudhu (purification) before going to bed, recite Aayatul Kursi}

Sihr doesn't affect a person in a state of wudhu; for he is protected by an Angel sent by the Merciful Allah. Ibn Abbas (may Allah have mercy on him) reported: "The Prophet (pbuh) said, "Wash these bodies and Allah (May He be glorified and exalted) will wash you. There is not a servant, who sleeps in a state of wudhu, but an Angel accompanies him in his clothes; and there is not a moment that he moves in bed, but that the Angel says: 0 Allah! Forgive Your servant, for he has slept in a clean state." (Transmitted by At-Tabarani in Al-Awsat. According to Al-Mundiri, the chain of transmission is very good (At-Targhib: 2/13) More wudhu, more prayers, fasting will give more protection and more rewards from Allah

\section{Ignore Satanic whispers (waswasah)}

The unwanted obsessive thoughts are called waswasah, whispered by Shaytan into the minds and hearts of people. "Say: 'I seek refuge with Allah, the Lord of mankind, the King of mankind, the God of mankind, from the evil of the whispers of the Devil, who whispers in the hearts of men" (Quran, a Nas 114). And the Prophet Muhammad (pbuh) said: "Shaytan comes to one of you and says, 'Who created so-and-so and so-and-so?' till he says, 'Who has created your Lord?' So, when he inspires such a question, one should seek refuge with Allah and give up such thoughts" (Bukhari and Muslim).

\section{Constant remembrance of Allah through Dhikr}

We should use Allah's remembrance (Dhikr) to ward off waswasah. Al-Nawawi (may Allah have mercy on him) said that "... when the Shaytan hears Dhikr (remembrance of Allah) he slinks away, and Laa ilaaha ill-Allah is the best of Dhikr, and the most effective remedy for warding off waswasah is to remember Allah a great deal."

"Verily, in the remembrance of Allah do hearts find rest." (Quran, Ar-Ra'd 13:28) "And whoever is blinded from remembrance of the Most Merciful - We appoint for him a devil, and he is to him a companion. And indeed, the devils avert them from the way (of guidance) while they think that they are (rightly) guided." (Quran, Az-Zukhruf 43:36-38) "And whoever turns away from My remembrance - indeed, he will have a depressed life, and We will gather him on the Day of Resurrection blind." (Quran, Taha 20:124)

\section{Faith and Trust in Allah}

"And whoever fears Allah and keeps his duty to Him, He will make a way for him to get out (of every difficulty). And he will provide him from (sources) he never could imagine" (Quran, AtTalaq: 2-3). "So, when you intend to recite the Quran, seek refuge with Allah from Shaytan, the outcast. Verily! He has no power over those who believe and put their trust only in their Lord (Allah). His power is over those who obey and follow him (Shaytan) and those who join partners with Allah" (Quran a Nahl 16:99-100). "Indeed, over My (believing) servants there is for you no authority. And sufficient is your Lord as Disposer of affairs." (Quran, Al Isra 17:65) "Say (O Muhammad): "Verily, my Salah (prayer), my sacrifice, my living, and my dying are for Allah, the Lord of the Alamin (mankind, jinn and all that exists)." (Quran, Al-An'aam 6:162)" Truly, Allah defends those who believe." (Quran, Al-Hajj 22:38)

\section{Fearing Allah and not His Creation}

"Satan threatens you with poverty and orders you to immorality, while Allah promises you forgiveness from Him and bounty. And Allah is all-Encompassing and Knowing." (Quran, Al Baqarah 2:268) "That is only Satan who frightens (you) of his supporters. So, fear them not, but fear Me, if you are (indeed) believers." (Quran, AlImran 3:175) The Prophet (pbuh) said to 'Umar ibn al-Khattaab: "So the Shayateen - the Jinn, they are scared of the Believers, but they have a sense, they can feel the fear and fright of mankind. So, if you become scared of Jinn, they become brave and they start scaring you."

\section{Obtaining Islamic knowledge (from the Right Sources)}

Taking heed of Satan's ways and becoming aware of his plans and goal can help us to be alert to his influence or persuasion and keep our defenses up. Imam Shafai said: “All humans are dead except 
those who have knowledge; and all those who have knowledge are asleep except those who do good deeds; and those who do good deeds are deceived except those who are sincere; and those who are sincere are always in a state of worry."

\section{Taking refuge and shelter in Allah}

"And if an Evil whisper comes to you from Shaytan (Satan), then seek refuge with Allah. Verily, He is All-Hearer, All-Knower" (Quran, Al-Aaraf: 200) This is what the Prophet (pbuh) did with the devil who put a flame of fire in his face, he said:" I seek refuge in Allah from you, and I curse you with the curse of Allah." He said that three times.

\section{When night comes as the Shayateen are active during the night}

It was narrated from Jaabir ibn 'Abd-Allaah (may Allah be pleased with him) that the Prophet (pbuh) said: "When the wings of the night spread or when evening comes - keep your children in, for the devils come out at that time. Then when part of the night has passed, let them go. And close the doors and mention the name of Allah (Bismillah), for the Shaytan does not open a closed door. And tie up your waterskins and mention Bismillah, and cover your vessels and mention Bismillah, even if you only put something over them, and extinguish your lamps." Narrated by al-Bukhaari (3280) and Muslim (2012): "Cover vessels, tie up waterskins, close doors and extinguish lamps, for the Shaytan does not loosen waterskins or open doors or uncover vessels."

\section{Islamic etiquettes and manners (code dress, lower the gaze) as a protection}

"And tell the believing women to reduce (some) of their vision and guard their private parts and not expose their adornment except that which (necessarily) appears thereof and to wrap (a portion of) their headcovers over their chests and not expose their adornment except to their husbands, their fathers, their husbands' fathers, their sons, their husbands' sons, their brothers, their brothers' sons, their sisters' sons, their women, that which their right hands possess, or those male attendants having no physical desire, or children who are not yet aware of the private aspects of women. And let them not stamp their feet to make known what they conceal of their adornment. And turn to Allah in repentance, all of you, 0 believers, that you might succeed." (Quran, A Noor 24:31)

\section{After Fajr prayer to recite 100 times}

"La ilaha illallahu wahdahu la sharika lahu lahul mulku wa lahul hamdu wa huwa 'ala kulli shay in qadir"

"Whoever recites "La ilaha illallahu wahdahu la sharika lahu lahul mulku wa lahul hamdu wa huwa 'ala kulli shay in qadir" one hundred times in the day will receive the reward of freeing 10 slaves, one hundred rewards will be written for him and one hundred sins wiped away, and he will be protected from Shaytan for the remainder of the day." (Sahih Bukhari, Hadith: 3293 and Sahih Muslim, Hadith: 2691)

\section{Say the following invocation: "He who recites three times every morning and evening:}

'Bismillahil-ladhi la yadurru ma`as-mihi shai'un fil-ardi wa la fis-sama'i, wa Huwas-Sami'ul-'Alim (In the Name of Allah with Whose Name there is protection against every kind of harm in the earth or in the heaven, and He is the All-Hearing and All-Knowing, nothing will harm him." (At-Tirmidhi 5/133)

\section{Dates against withcraft}

The Prophet (pbuh) said: "Whoever eats seven 'ajwah dates in the morning, will not be harmed by any poison or witchcraft that day." (Bukhari 5445 and Muslim 2047).

\section{Truffles (Mushroom)}

Prophet Muhammad (pbuh) said: "The truffle is among the Mann (Allah's favours) and its water cures the eye" (Bukhari). It was said that among the Manna sent down by Allah to the Children of Israel were several plants that grow in the wild without effort. Some scholars consider truffles to be a kind of Manna, althought the word Manna in the Quran refers to the sweet dew that descended from the trees (Jauziyah, 2003). The Hadith mentioned: "Heaven laughed, it produced truffles, and the Earth laughed and produced capers." Truffles grow wild underground and they are a type of fungi sometimes regarded as a mushroom and they have a strong flavor and fragrance.

\section{FASTING is against all diseases}

The last Messenger of Allah (pbuh) was fasting Monday and Thursday and three days of the Full Moon. There are many other non-obligatory fasting days with health benefits and rewards from Allah. Dr Mizushima showed that the autophagy serves as a dynamic recycling system that produces new building blocks and energy for cellular renovation and homeostasis against all diseases and anti-aging effects. [14]

\section{CONCLUSION}

The Messenger of Allah (pbuh), sent to all mankind, said: There is no disease that Allah has created, except He also has created its treatment." (narration by Abu Hurayra, Bukhari) Jinn Possession has been well-documented since Hippocrates (born around the year $460 \mathrm{BC}$ ) period. But the term Jinn Possession is seldom mentioned in Medicine. Instead, the doctors speak about the diseases with unknown causes and their symptoms are treated with drugs which take effect by turning the patients into virtual vegetables. Imam Ibn Taymiyyah (may Allah have mercy upon him), who died more than 700 years ago, said in al-Fatawaa the following excellent statement, "If the veil were removed from the people of this time we would find most of the people are possessed by demons." If that was the case 700 years ago, what can we say about this age in which filth is widespread and the means of demonic possession are abundant. This is a time of sport and play, disobedience and corruption. This can only witness how far people went from our Creator, Allah.

The exorcism by any other means, except Quran (for example, calling upon Jesus or other human or idols) is a shirk, means the 
sin of practicing idolatry or polytheism, i.e. the deification or worship of anyone or anything besides the singular God, i.e. Allah. Literally, it means ascribing or the establishment of "partners" placed beside God. It is the vice that is opposed to the virtue of Tawhid (monotheism). The Jinn may leave because the person who performs the exorcism calls upon others (Jesus) rather than Allah, so committing shirk the Jinn have got what wanted, misguide people. It helps consolidate people's kufr and shirk and makes them firm in their path towards Hellfire, which is what Shaytan's goal for humanity. Another sort of the shirk, when the Jinn causing disease can be kicked by another Jinn, so the present symptoms may disappear but later on there will be other problems. Many manipulations with exorcism are done in the West and in the East using other means than Quran.

The knowledge about Jinn diseases and exorcism by Quranic verses should be in all Medical Institutions in order to help mankind achieves bliss in this life and to have the Allah's rewards. Ibn Taymiyyah (may Allah have mercy upon him) said in his book, Al-Fatawaa, "Applying this knowledge of Quranic medicine is compulsory upon whoever learns it. Because it is equivalent to relieving the troubled, helping the oppressed, liberating the distressed and supporting the weak. And Allah mentions Negative Ions Treatment (Rain) in Quran: “...sent down upon you from the sky, rain by which to purify you and remove from you the evil [suggestions] of Satan and to make steadfast your hearts and plant firmly thereby your feet." (Quran, Al-Anfal 8:11)

\section{REFERENCES}

1. Noboru Horiguchi (2012) Science: Power of negative Ions.

2. Earl Mindell (2015) The Happiness Effect: The Positive Benefits of Negative Ions.

3. Jean Yves Cote (2008) The Ion Miracle: The Effects of Negative Ions.

4. Pierce J Howard (2006) The Owner's Manual for the Brain: Everyday Applications from Mind Brain Research and director of research at the Center for Applied Cognitive Sciences in Charlotte, North Carolina, USA.

5. Ibn Taymiyah's (2007) Essay on the Jinn (Demons).

6. Abul Mundhir Khaleel (2009) The Jinn and Human Sickness] Remedies In The Light Of The Quran and Sunnah.

7. Wahid Ibn Abdessalam Bali (2004) Sword against Black Magic and Evil Magicians.

8. Abdul Azeez Bin Abdullah Bin Baaz (2007) The Ruling of Sorcery, Fortune-Telling and Related Issues.

9. Ibn Qayyim Al Jawziyyah (2017) Provisions for the Hereafter: (Zad Al Ma'ad).

10. Mira Bajirova (2018) Infertility caused by Decreased Oxygen Utilization and Jinn. Archives of Reproductive Medicine and Sexual Health 1(1): 4758.

11. Mira Bajirova (2018) Infertility caused by Jinn. Journal of Reproductive System and Sexual 1(4): 1-14.

12. Bilal Philips (1994) Exorcism Tradition in Islam.

13. Muhammad Tim Humble (2017) A Simple Guide to Self Ruqyah.

14. Noboru Mizushima (2011) Autophagy: Renovation of Cells and Tissues. Cell 147(4): 728-741.
This work is licensed under Creative Commons Attribution 4.0 License

Submission Link: Submit Article

DOI: 10.32474/OAJRSD.2018.01.000123

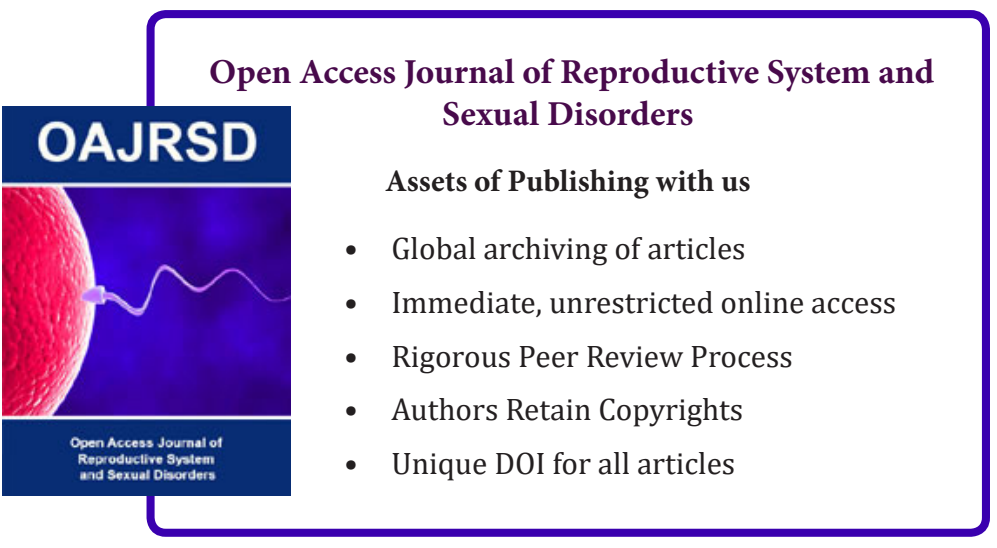

